\title{
Changes in the expression of BNIP-3 and other neuronal factors during the cultivation period of primary cultured rat cerebral cortical neurons and an assessment of each factor's functions
}

\author{
Michihisa Tohda \\ Correspondence: tohdam@inm.u-toyama.ac.jp

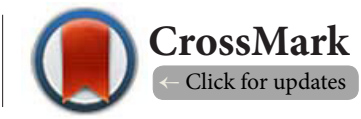 \\ Division of Medicinal Pharmacology, Institute of Natural Medicine, and Wakan-yaku Theory-Based Integrated Pharmacology, \\ Graduate School of Innovative Life Science, University of Toyama, Toyama 930-0194, Japan.
}

\begin{abstract}
The degree of RNA editing of the 5-HT2C receptor dramatically changes during the cultivation period of primary cortical neurons. In this report, the changes in the mRNA expression levels of some factors that are essential to neuronal functions were determined using semi-quantitative reverse transcription polymerase chain reaction (RT-PCR) methods. The results suggested that neurite re-extension occurred until 9 or 12 days after starting the culture. This re-extension was followed by the reconstitution phase of the synapse. Based on this observation, the mRNA expression changes of BNIP-3, which is reportedly involved in depression and/or the actions of antidepressants in addition to be involved in mitochondrial cell death, were examined to determine its physiological functions beyond the previously reported mitochondrial cell death process. The results suggested that BNIP-3 also has basic cellular functions because its mRNA expression was detected during the early stages of the culture, was not inducible, and maintained a constant expression level during the culture period. The neuronal primary cell culture system may mimic the reconstruction process of a neuron recovering from damage. This system may be useful in estimating the physiological roles of the intrinsic factors and determining the pharmacological effects of drugs.
\end{abstract}

Keywords: Primary cultured neurons, RNA expression, cultivation duration, antidepressant, neurite elongation

\section{Introduction}

Using primary cultured cortical neurons, we have previously reported [1] that the frequency of RNA editing at each of the 5 parts $\left(A, B, C, D\right.$, and $E$, from the $5^{\prime}$-side) of the serotonin $2 C$ subtype receptor (5-HT2CR) RNA, which are located in the second intracellular loop domain coding site and have different susceptibilities, is not always constant during the cultivation period. These changing patterns were mimicked during the development of the newborn rat brain and may indicate that the neurons isolated for primary cell culture develop various physiological factors in a time dependent manner that is based on their physiological roles in neural construction or reconstruction. To prove this hypothesis, we first observed the variations that occurred in the mRNA expression patterns of various known factors throughout the cultivation periods of these cells. The observation and comparison of the expression patterns of novel factors (or factors with functions that are unknown to other known factors) may provide insight into the neuronal development stages in which they participate.

We have also previously reported [2] that the $\mathrm{BCL} 2$ /adenovirus E1B 19-kDa protein-interacting protein 3 (BNIP-3) is a target candidate for the intrinsic factors (e.g., monoamine transporters) related to antidepressant actions. Enhanced BNIP-3 mRNA expression in the NG108-15 cells, hybrid cells of mouse neuroblastoma and rat glioma, was observed after the cells were exposed to Hochuekkito, a Wakan-yaku prescription, and also they were exposed to typical antidepressants [2]. Imipramine also enhanced the BNIP-3 mRNA expression in the brain in a mouse model of depression [3]. However, the physiological functions of BNIP-3 have not been fully clarified. It has been suggested that BNIP3-mediated apoptosis occurs independent of caspase activation and cytochrome $C$ release and is characterized by damage to the early plasma membrane and mitochondria prior to the appearance of the chromatin condensation or DNA fragmentation that is related to small RNA function [4]. Additionally, BNIP-3 mRNA is not inducible and is expressed in non-stimulated/steady-state cells [2]. BNIP-3 may have physiological functions in processes other than cell death.

To estimate the physiological function of BNIP-3, we demonstrated the mRNA expression patterns of various typical neuronal/synaptic factors, including BNIP-3, during the cultivation periods of primary cortical neurons.

\section{Materials and methods \\ Primary neuronal cell cultures}

Cortical neuronal cell culture was performed as previously described [5]. Briefly, the cerebral cortices from E20 embryos were placed in Neuronbasal ${ }^{\mathrm{TM}}$ Medium supplemented with 
Michihisa Tohda, Cell signalling and Trafficking 2014,

http://www.hoajonline.com/journals/pdf/2054-1481-2-1.pdf

doi: 10.7243/2054-1481-2-1

$12 \%$ horse serum, $0.6 \%$ glucose, and $2 \mathrm{mM} \mathrm{L-glutamine} \mathrm{(glu[+]}$ medium), minced with sterilized scissors, and incubated at $37^{\circ} \mathrm{C}$ for $15 \mathrm{~min}$ in $2 \mathrm{ml}$ of $0.05 \%$ trypsin solution (Gibco, U.S.A.). Then, $4 \mathrm{ml}$ of $\mathrm{glu}(+)$ medium was added to the suspension to inhibit the trypsin activity, and the medium was centrifuged at $800 \mathrm{rpm}$ for $7 \mathrm{~min}$. The resulting pellet was suspended in $2 \mathrm{ml}$ of phosphate buffered saline (PBS) containing $100 \mathrm{U} / \mathrm{ml}$ DNase I and incubated for $15 \mathrm{~min}$ at $37^{\circ} \mathrm{C}$. After adding $4 \mathrm{ml}$ of the medium, the centrifugation step was repeated. The final pellet was resuspended in $4 \mathrm{ml}$ of glu(+) medium, triturated through a special Pasteur pipette, and filtered through a 70$\mu \mathrm{m}$ cell strainer (BD Falcon, U.S.A.) to isolate the individual cells. A small amount of the cell suspension was stained with $0.2 \%$ trypan blue to determine the cell viability and density. The cells ( $3.6 \times 10^{6}$ cells/dish) were plated onto $60-\mathrm{mm}$ dishes that were pre-coated with $5 \mu \mathrm{g} / \mathrm{ml}$ of poly D-lysine (Sigma USA, polymerization 30,000-70,000), dissolved in PBS, and cultured at $37^{\circ} \mathrm{C}$ in an atmosphere of $10 \% \mathrm{CO}_{2}$ and $90 \%$ air for 4-6 hrs. The medium was then changed to serum-free glu(+) medium supplemented with B-27 (Gibco, U.S.A.). To study the effects of imipramine, the drug was applied to the culture medium in a 100-fold concentrated solution. The treatment lasted 2 days.

Total RNA extraction and reverse transcription-polymerase chain reaction (RT-PCR)

Total RNA was extracted from rat cerebral cortices and primary cultured cerebral cortex cells using TRIsure ${ }^{\mathrm{TM}}$ (Nippon Genetics, Tokyo, Japan), according to the manufacturer's instructions. Total RNA $(1 \mu \mathrm{g})$ was incubated with $0.5 \mu \mathrm{M}$ oligo(dT) primer and $1 \mathrm{ml}$ of ReverScript ${ }^{\circledR} \mathrm{III}$ (Wako, Oosaka, Japan) at $37^{\circ} \mathrm{C}$ for $60 \mathrm{~min}$, according to the manufacturer's instructions. The single-stranded complementary DNA synthesized by the reverse transcription was used as a PCR template. The specific primers for each factor, the estimated product size, and the optimal detection cycles are listed in Table 1. The PCR mixture contained $0.5 \mu \mathrm{l}$ of RT product, $0.5 \mu \mathrm{M}$ sense and antisense primers, $0.25 \mathrm{mM}$ dNTPs, $2.5 \mathrm{mM} \mathrm{MgCl}$, and 2 units of Taq DNA polymerase in the reaction buffer. PCR was performed in the following manner: 1) $94^{\circ} \mathrm{C}$ for $3 \mathrm{~min}$; 2) optimal cycles (Table 1) of $94^{\circ} \mathrm{C}$ for $30 \mathrm{~s}, 65^{\circ} \mathrm{C}$ or $57^{\circ} \mathrm{C}$ for $1 \mathrm{~min}$, and $72^{\circ} \mathrm{C}$ for 1 min; and 3) $72^{\circ} \mathrm{C}$ for $5 \mathrm{~min}$ before cooling to $4^{\circ} \mathrm{C}$. The products were resolved with $6 \%$ polyacrylamide gel electrophoresis and stained with ethidium bromide. The bands were visualized under UV light and quantified using Densitograph software, version 4.0 (ATTO, Tokyo, Japan).

\section{Detection, isolation and sequencing of the BNIP-3 mRNA variant}

To read the sequences, the bands were cut out after photographing the gel under a UV transilluminator. The gel slices were heated at $90^{\circ} \mathrm{C}$ in $100 \mu$ l of water for $12 \mathrm{~min}$. Using the supernatant as a template, PCR re-amplification was performed with the same pair of primers that had been used in the initial
Table 1. The primer sets used in the RT-PCR.

\begin{tabular}{|c|c|c|c|c|c|}
\hline & & Size & Cycle & Forward & Backward \\
\hline Mbp & AF439750 & 286 & 30 & $\begin{array}{l}\text { cat cac aga aga } \\
\text { gac cct ca }\end{array}$ & $\begin{array}{l}\text { ggt gta cga ggt } \\
\text { gtc aca at }\end{array}$ \\
\hline IDE & NM031156 & 308 & 27 & $\begin{array}{l}\text { gac cct cca aat } \\
\text { att cct gg }\end{array}$ & $\begin{array}{l}\text { agt ctc cag gca } \\
\text { tcg ttc at }\end{array}$ \\
\hline $\begin{array}{l}\text { Neprilysin } \\
\text { (-like) }\end{array}$ & AF302075 & 356 & 35 & $\begin{array}{l}\text { agc ctg agc cag } \\
\text { aga ttc aa }\end{array}$ & $\begin{array}{l}\text { ctg gag tat tcc } \\
\text { tca tcc ga }\end{array}$ \\
\hline $\begin{array}{l}\text { M-CSF } \\
\text { receptor (fms) }\end{array}$ & X61479 & 312 & 28 & $\begin{array}{l}\text { agg cag tac cac } \\
\text { cat cca ctt tgt ta }\end{array}$ & $\begin{array}{l}\text { ttc acc tta agc } \\
\text { cag atg cca gtg }\end{array}$ \\
\hline M-CSF & M84361 & 272 & 30 & $\begin{array}{l}\text { ggt gga act gcc } \\
\text { agt ata ga }\end{array}$ & $\begin{array}{l}\text { ctc cag ggc cca } \\
\text { caa taa at }\end{array}$ \\
\hline APP & NM019288 & 261 & 23 & $\begin{array}{l}\text { aat cct gca gta } \\
\operatorname{ctg} c c a \text { ag }\end{array}$ & $\begin{array}{l}\text { tgg caa cag tat } \\
\text { gcc agt ga }\end{array}$ \\
\hline $\begin{array}{l}\text { Symaptotag- } \\
\text { mine-1 }\end{array}$ & NM001033680 & 545 & 24 & $\begin{array}{l}\text { tga gtg cca gtc } \\
\text { atc ctg ag }\end{array}$ & $\begin{array}{l}\text { gac ttt gac gta } \\
\text { tgg atc gg }\end{array}$ \\
\hline $\begin{array}{l}\text { Muscarinic } \\
\mathrm{ml}\end{array}$ & NM080773 & 408 & 29 & $\begin{array}{l}\text { act gtc ttg gca } \\
\text { cca gga aa }\end{array}$ & $\begin{array}{l}\text { tgc tag gcc aat } \\
\text { cat cag ag }\end{array}$ \\
\hline $\begin{array}{l}\text { Muscarinic } \\
\text { m3 }\end{array}$ & NM012527 & 305 & 27 & $\begin{array}{l}\text { taa ctg gct tcc } \\
\text { tgg cat tg }\end{array}$ & $\begin{array}{l}\text { tag gtg agt ggc } \\
\text { cta gtg at }\end{array}$ \\
\hline $\begin{array}{l}5 \text {-HT2C } \\
\text { receptor }\end{array}$ & NM008312 & 279 & 27 & $\begin{array}{l}\text { gcc ttt acc tag } \\
\text { ata ttt gtg ccc } \\
\text { cgt ctg }\end{array}$ & $\begin{array}{l}\text { atg cca cga agg } \\
\text { acc cga tga gaa } \\
\text { cga agt }\end{array}$ \\
\hline Nicotinic $\alpha_{7}$ & NM012832 & 455 & 28 & $\begin{array}{l}\text { ctc tga ctg tct } \\
\text { tca tgc tg }\end{array}$ & $\begin{array}{l}\text { gtg cat gag } \\
\text { gtgctc atc at }\end{array}$ \\
\hline PSD-95 & D50621 & 394 & 30 & $\begin{array}{l}\text { acc gct acc aag } \\
\text { atg aag ac }\end{array}$ & $\begin{array}{l}\text { atg gaa ccc gcc } \\
\text { tct ttg ag }\end{array}$ \\
\hline$\beta$-actin & V01217 & 222 & 18 & $\begin{array}{l}\text { gtg aca gca ttg } \\
\text { ctt ctg tg }\end{array}$ & $\begin{array}{l}\text { aac ggt ctc acg } \\
\text { tca gtg ta }\end{array}$ \\
\hline BNIP-3 & NM009760 & 173 & 30 & $\begin{array}{l}\text { gat tgg tca agt } \\
\text { cga cca ga }\end{array}$ & $\begin{array}{l}\text { gcc agc aga tga } \\
\text { gac agt aa }\end{array}$ \\
\hline
\end{tabular}

The estimated product sizes are calculated from the reported applicable sequences. Each optimal number of cycles for detection of RNA expression was determined from the basic experiment of the cycle dependency.

reaction. The amplified DNA fragments were purified using the MonoFas DNA purification kit (GL Science, Tokyo, Japan). The sequence of the isolated fragment was read by direct sequencing using each specific primer for detection with a sequence 310 Genetic Analyzer ( $\mathrm{ABI}, \mathrm{CA}, \mathrm{USA})$.

\section{Results}

The expression patterns of various neuronal functional factors during the cultivation periods of primary cultured cortical neurons

During the cultivation period of the primary cells, the mRNA expressions of the various interesting neuronal factors were determined using semi-quantitative RT/PCR (Figure 1). The myelin basic protein (MBP) showed the most dramatic change (Figure 1A); its expression level peaked at day 9, followed by a dramatic decrease. The expression changes that peaked at day9 were also observed in the insulin-degrading enzyme (IDE), the macrophage-colony stimulating factor (M-CSF), and the receptor (M-CSFR [fms]) (Figure 1A). The mRNA expressions of these 3 factors continued at this level or increased again after day 12 , suggesting that these 3 factors still performed functions after day 12. Another group (Figure 1B) contained 4 factors (i.e., the muscarinic $\mathrm{m} 3$ receptor 


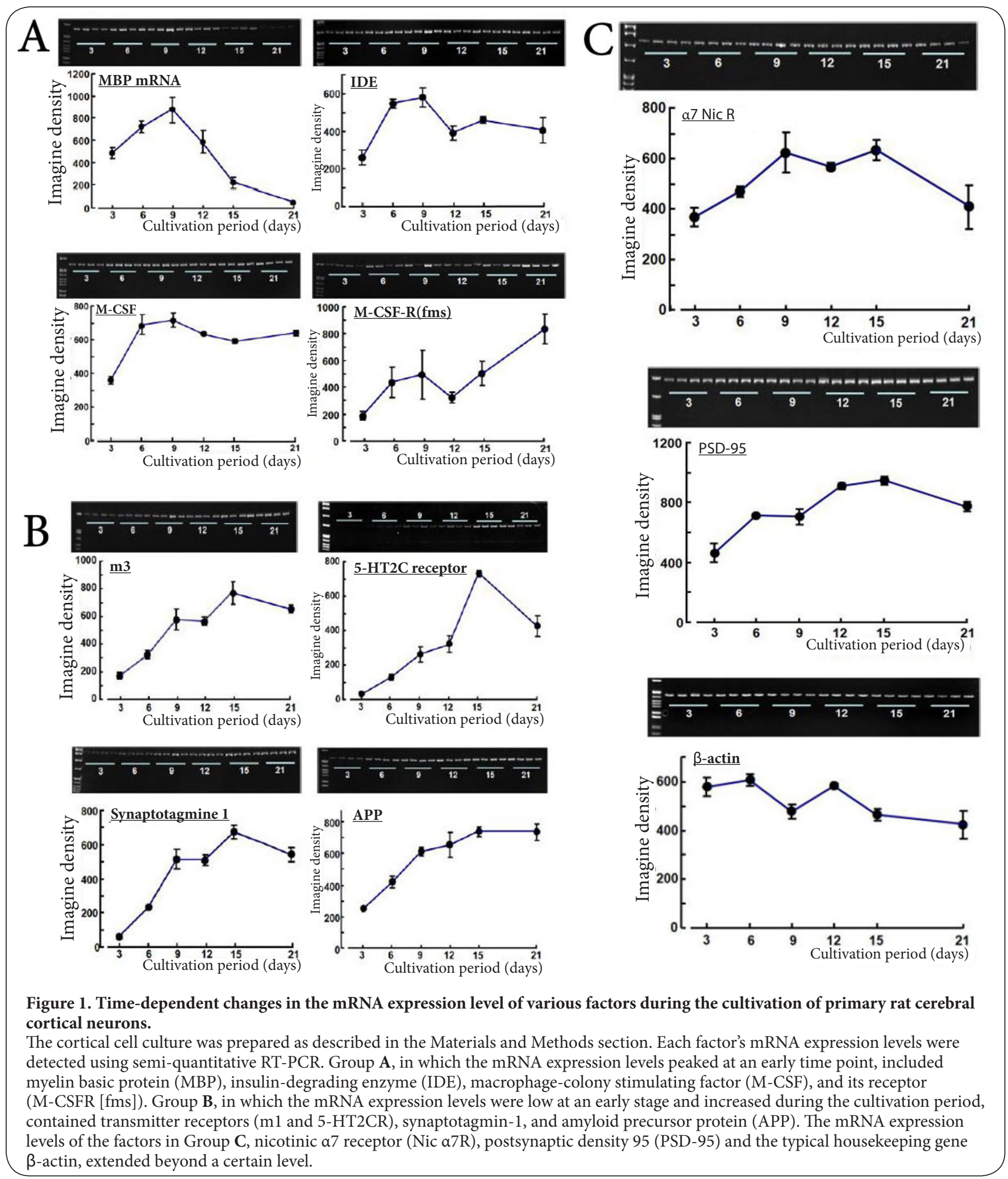

subtype $[\mathrm{m} 3]$, serotonin $2 \mathrm{C}$ receptor subtype [5-HT2CR], synaptotagmine-1, and amyloid precursor protein [APP]) with different expression patterns; their expression levels increased during the cultivation period. The expression levels of these factors were low at day 3. Meanwhile, the RNA expression levels of the following 3 factors were beyond a certain level: 
Michihisa Tohda, Cell signalling and Trafficking 2014,

http://www.hoajonline.com/journals/pdf/2054-1481-2-1.pdf

doi: 10.7243/2054-1481-2-1

the nicotinic $\alpha 7$ receptor (Nic $\alpha 7 \mathrm{R}$ ), the postsynaptic density 95 (PSD-95), and the typical housekeeping gene $\beta$-actin (Figure 1C). The RNA expression of these factors did not change greatly throughout the cultivation period, but the Nic $\alpha 7 \mathrm{R}$ and PSD95 levels increased slightly until day 15.

Changes in the expression of BNIP-3 mRNA in primary cultured cortical neurons and the influence of imipramine treatment

Based on the results detailed above, to estimate its function, the BNIP-3 mRNA expression was examined by weighing the similarities in the expression patterns. Its expression appeared to be similar to the previous group, which included Nic $\alpha 7 R$ and PSD-95 (Figure 2). When the BNIP-3 mRNA was detected, a small band corresponding to a lower molecular weight was also detected, like in the case of short variant of $5-\mathrm{HT} 2 \mathrm{CR}[6,7]$. Although only weak bands can be seen in Figure 2, the expression strength varied depending on the lot of the primary cell culture. The small bands were remarkably visible, as shown in Figure 3.

In our previous report [2], the BNIP-3 mRNA expression was enhanced by antidepressants in the cloned cultured NG108-15 cell line. Therefore, the effect of imipramine on BNIP-3 mRNA expression in the primary cultured cells was examined. As mentioned above, 2 bands of PCR products were observed in

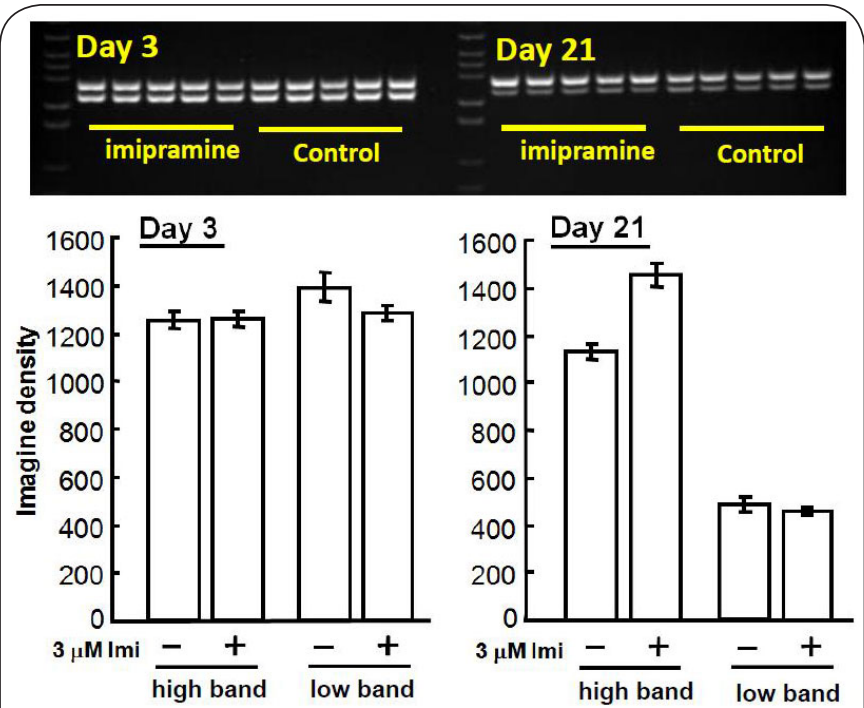

Figure 3. Effect of imipramine treatment on the mRNA expression of BNIP-3 and its short variant in the primary cultured cortical neurons.

The cortical cell culture was performed as described in the Materials and Methods section. The cells were cultivated for either 1 or 19 days and treated with $3 \mu \mathrm{M}$ imipramine for the following 2 days. The expression levels of BNIP-3 and its short variant mRNA were detected using semi-quantitative RT-PCR.

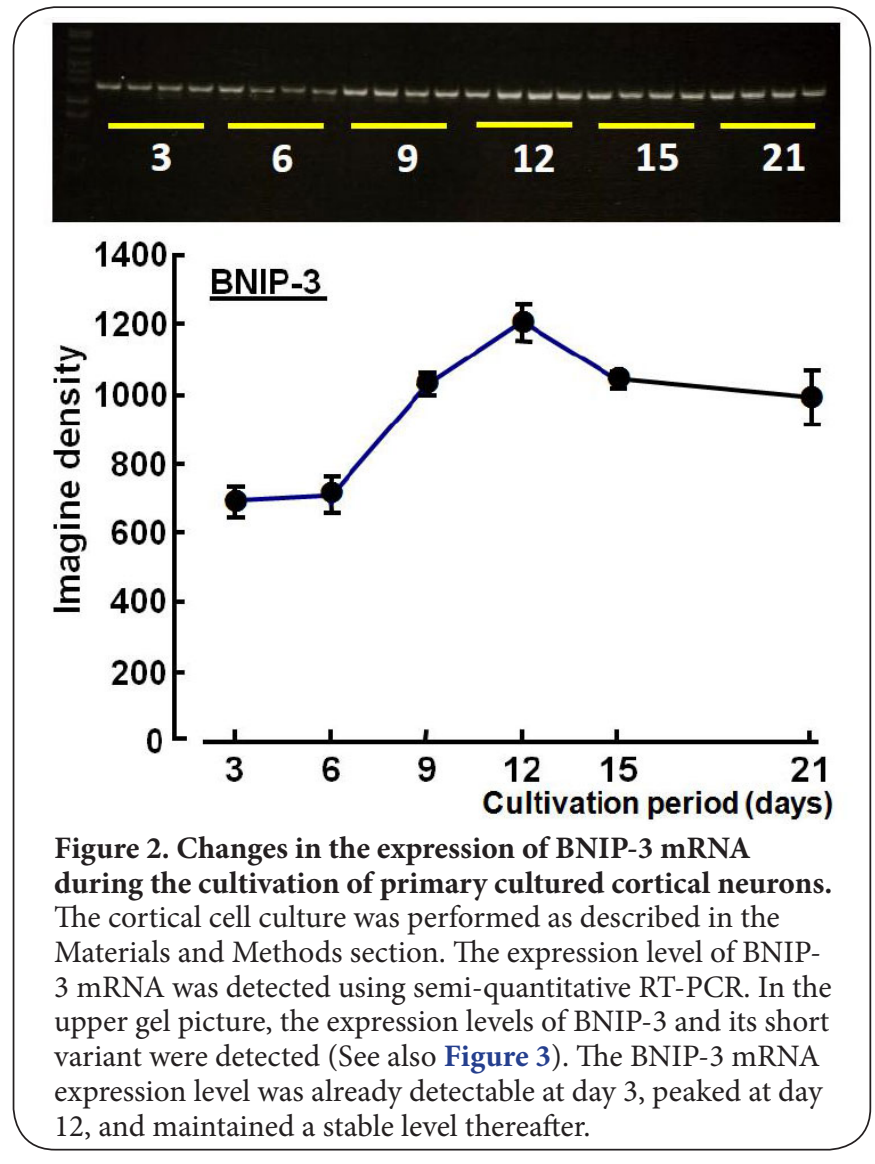

1 primer pair (Figure 3 ), although these bands appear weaker in Figure 2. Between the 2 bands, the band that appeared at $173 \mathrm{nt}$ was consistent with the sequence of BNIP-3 mRNA (as later described). The expression of BNIP-3 mRNA was not affected by imipramine in the primary cultured cell at day 3 , but its expression was higher at day 21 , which was also observed inthe NG108-15 cells. Meanwhile, the expression of the lower band, which strongly decreased from days 3 to 21, was not affected by imipramine on either day (Figure 3 ).

The sequence of a possible variant of BNIP-3 mRNA Both bands were cut out from the gel and reamplified to read the sequence (Figure 4). The sequence of the main band was the same as the reported BNIP-3 mRNA sequence. Meanwhile, the short variant included the irregular deletions of 11 bases and 13 base substitutions, as compared to the reported BNIP3 mRNA sequence.

\section{Discussion}

This report makes the following observations: 1) various intracellular factors are sequentially expressed to reconstruct neural networks during the cultivation period of cells isolated from rat cerebral cortex cells; and 2) the BNIP-3 mRNA expression, which is reportedly elevated by antidepressant treatment in cloned cells [2], had the same expression pattern as the $\alpha 7$ and PSD-95 mRNAs during the cultivation period of rat cerebral cortex cells. The estimated significance of 


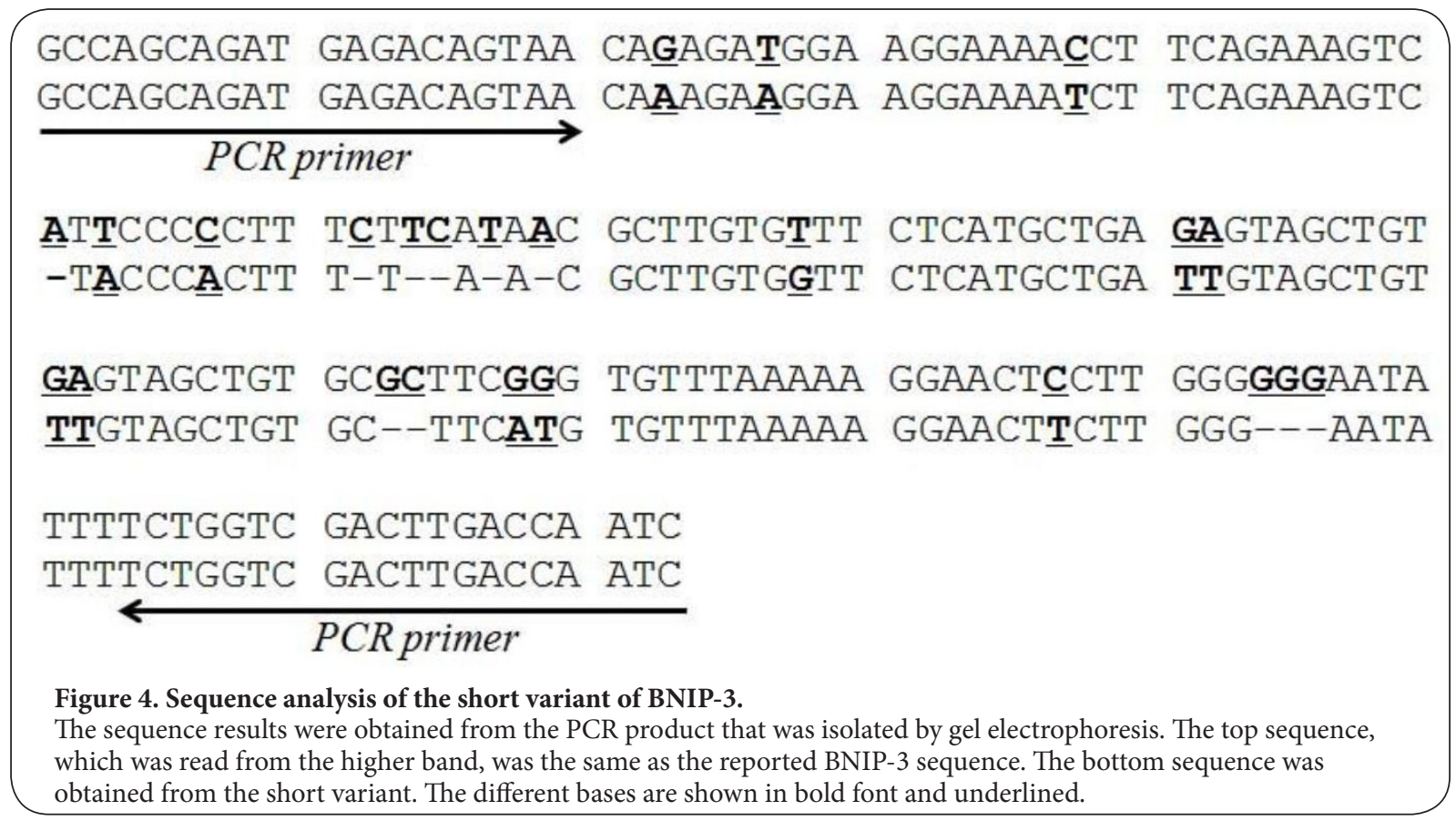

this result will be discussed later. 3) The 11 bases that were deleted from the RNA were also detected with the probe that was used to detect BNIP-3 mRNA by PCR. The BNIP-3 mRNA expression level was higher during the earlier time points of the culture, and its strength varied depending on the culture batch.

Because only a few factors were analyzed in this report, future experiments should be conducted to evaluate additional factors. However, among the detected factors, it appears that the patterns of mRNA expression changes can be classified by three patterns: group 1 the expression peaks at days 9 or 12; group 2 the expression at the beginning of the culture period is low and increases linearly (approximately) during the cultivation period; and group 3 the expression is almost constant during the cultivation period, although small changes are observed. In the group 1, MBP showed a dramatic expression change, peaking at day 9 (followed by remarkable attenuation). This result suggests that the neuritic extension progresses until day 9 (approximately) and that myelination is needed in theprocess. MBP production is accelerated by the elevation of its mRNA expression. Regarding the remarkable decrease in the MBP mRNA expression level that occurs after day 9, the activation peak of the neurite elongation is estimated at day 9 or slightly thereafter. In this manner, determining the mRNA expression changes can provide insight into the dynamic changes of the physiology of the primary cultured neuronal cells. [detate the sentence previously here] In addition to MBP, IDE, M-CSF and its receptor (M-CSF-R) also showed peak expression at day 9 (approximately). IDE plays a role in degrading insulin and $A \beta$ [8]. Because of its functions, it is believed that the mRNA expression of IDE is maintained at a certain level after the expression peak at day 9, unlike MBP. In a similar manner, M-CSF and M-CSF-R maintained their expressions after day 9 for their functions as a signaling molecule and a receptor, respectively. Note that the expression of M-CSF-R mRNA increased again linearly after day 12 , similar to the expression of the receptor group pattern mentioned below.

It is common that M-CSF is involved in the stimulation of the macrophage function. M-CSF also reportedly has functions in neuroprotective properties $[9, \mathbf{9}, \mathbf{0}]$. From these report, it cannot be ruled out that there are small amount of glial cells contaminated in this primary cultured neuronal cell system and worked for development of neuron. Meanwhile, $\mathrm{M}-\mathrm{CSF}$ is also reportedly expressed in neuron [11]. It can be thought that M-CSF induced the neuronal self-activation through like an autocrine system in this neuronal culture. Since the details will be a future study, the participation of this M-CSF factor will be interesting as a neuronal essential function. These factors, IDE, M-CSF and M-CSF-R, may have physiological functions for transcriptional activity until day 9, followed by their individual (different) functions. In fact, M-CSF-R is also known as "fms," an oncogene that is involved in Alzheimer's disease [12]. IDE also has multiple functions [13]. These factors all have multiple roles, displaying different functions depending on the state of the neuronal cells.

Group 2, which showed lower expression levels in the early stage and increased linearly with the cultivation period, included $\mathrm{m} 3$ and $\mathrm{m} 1$ (data not shown), 5-HT2CR, synaptotagmin 1, and APP. It may be hypothesized that, similar to synaptotagmin 1 and APP, $\mathrm{m} 3$ and 5-HT2CR are also involved in synaptic functions. 5-HT2CR,m3, and M-CRF-R are neuro- 
Michihisa Tohda, Cell signalling and Trafficking 2014,

http://www.hoajonline.com/journals/pdf/2054-1481-2-1.pdf

doi: 10.7243/2054-1481-2-1

transduction receptors. Synaptotagmin 1 participates in endocytosis in the synapse as a $\mathrm{Ca}^{2+}$ sensor [14]. Meanwhile, APP is well-known as a precursor of $A \beta$, a factor that causes Alzheimer's disease. It is also well known that various enzymes act on APP to produce various types of active factors with neuronal functions $[15,16]$. Under normal conditions (i.e., not in disease), APP is cut by $\alpha$-secretase to produce the C-terminal fragments SAPP $\alpha$ and C83. SAPP $\alpha$ associates with the normal signal transmission of the synapse and works on synaptic plasticity, learning, memory, emotional actions, and nerve survival. Therefore, APP is necessary as a precursor to these factors to maintain both nerve and synaptic functions, andits mRNA expression pattern might be similar to the other synaptic factors in group 2. The 5-HT2CR mRNA expression suddenly increased at day 15 . Because this result was also observed in other plural primary culture lots (data not shown), it appears to be a fact and not an artifact. The expression changes of the other factors belonging to this group maximized at day 15. Based on these observations, it may be hypothesized that some of the factors produced by the 5-HT2CR mRNA at day 15 serve physiological roles at the moment of synaptogenesis. Many reports have mentioned the various phenomena of $5-\mathrm{HT} 2 \mathrm{CR}$ mRNA, including the short variant of RNA $[7,17]$, the generation of the 95-nt fragment from the 5-HT2CR mRNA [17], the existence of the binding site for MBII-52 (a type of small RNA) [18], and the functional regulation of 5-HT2CR activity via RNA editing [19]. The 5-HT2CR mRNA product may serve an important function during the synaptic joining.

The determination of RNA expression was performed by the gel method and was not performed it by the real-time PCR. Since the real-time PCR has some faults, it did not use in this study, although real-time PCR could surely express the difference between expressions quantitatively. In the case of variant productions like 5-HT2CR (and BNIP-3) expression, the expression result is performed additively. Since when the PCR form double strand, the real-time PCR emits a signal, suggesting that it is not necessarily quantitative depending on the situation. In addition, when the expression is enough big difference (more than 2-fold), the real-time PCR methods give us the "real" quantitative date actually. However, when the difference is a little, this electrophoresis way can show that there is a difference definitely, although there is not the absolute quantifiability. When the result is time-dependent like this experiment, the gel methods is advantageous visually.

Based on these results, neurite extension activity is apparently strong until day 9 (after the start of the cultivation) and is followed by the synaptogenetic stage. At day 15, the synaptogenetic activity may peak. This observation, which is dependent on the duration of the cultivation in these primary cells, may mimic the reconstruction process of a neuron recovering from disorder damage.

Group 3, which had relatively constant expression since the beginning of the cultivation, included $\beta$-actin, PSD-95 and Nica7. Unsurprisingly, $\beta$-actin belongs to this group.
PSD-95 is known as a postsynaptic scaffold protein for the ionotropic receptors, particularly for the AMPA-type of glutamate receptors [20]. Based on the argument mentioned above, PSD-95 and Nica7, should not be necessary in the early stage because synaptogenesis may begin after day 9 (after the neurites are sufficiently extended). However, in this study, it was observed that the mRNA expression of these factors did not significantly change but slightly increased by day 15. The semi-quantitative methods of measuring mRNA expression in this experiment determined the expression levels compared to the maximum value among the samples. Therefore, if the difference among the samples is not large, the difference may appear larger than it is in reality. Small differences can be detectable with higher sensitivity using this method rather than real-time PCR methods. The degree of the expression change (depending on the cultivation period) in group 3 appears to be much weaker than the change in group 2. An increase of the expression levels in group 3 until day 15 is thought to be used for synaptic functions, similar to group 2. In addition, basic expression in the early stage may suggest that the factor in group 3 is related to the underlying function of the cell. PSD-95 is known to affect the synaptic plasticity in dendrites [21], and the translation is regulated in a short time by glutamic acid receptor stimulation [22]. It has been suggested that miR-125a, which is a small RNA participates in the translational control of PSD-95 [23]. PSD-95 mRNA may always exist under the cell membrane, waiting for the stimulation to be translated into protein. Meanwhile, Nica7 may be involved in the excitation of neurons and might also be the driving force of neurite extension [24]. Nica7 is reportedly related to Alzheimer's disease [25], thus Nica7 may be important for neurons. These arguments do not exceed the speculative level at this stage, but further experiments might prove that the factors belonging to group 3 are also involved in the basic part of cell existence in the early stage and not just in its functions in the late stage.

Based on the observations mentioned above, the BNIP-3 mRNA expression pattern appeared to be in group 3. Although BNIP-3 is well known to have the function of mitochondrial cell death [4], it is estimated that it also has basic cellular physiological functions because the expression pattern of the mRNA in the primary cultured neuronal cells belonged in type 3; the onset of mRNA was already observed in the early days of the culture (in this report), and the mRNA was expressed even in the non-stimulated/steady-state cloned cell line; thus, it is inducible [2]. The mRNA expression level increased during the cultivation date and peaked on day 12 , suggesting that it may have a role in neurite extension and/ or synaptogenesis. The PCR reaction used to detect BNIP-3 mRNA expression showed two bands. Although the expressed densities varied according to the lots of the primary cultured cells, the low molecular band was strongly detected in the early days of the culture, and it generally decreased during the cultivation. The sequence of the low molecular band 
could not be explained by splicing, or RNA editing of the high molecular weight BNIP-3 mRNA band. The expression of the low molecular band is thought to depend on the culture conditions because different expressions were observed among the culture lots. The expression level was strongly decreased in the mature cells. Further studies are necessary to clarify the function. It is expected that BNIP-3 may participate in cell survival in the early stage because a difference in its expression was observed among the culture lots.

We have previously reported that BNIP-3 mRNA increases by clonic treatment with antidepressants in a cloned cell line [2]. In the primary cultured neuronal cells used in this report, imipramine treatment also increased the expression of the high molecular band of BNIP-3 mRNA at day 21. However, the effect of imipramine was not observed on day 3 . It is more likely that imipramine influences the BNIP-3 mRNA expression in nerve cells after synaptogenesis, although the duration of the imipramine treatment may also be related. From these results, it is suggested that BNIP-3 or the related factors, which induced expression changes of BNIP-3 mRNA, participates in the antidepressant effect.

\section{Conclusion}

This report makes the following observations: 1) the mRNA expression of various factors dynamically changes during the cultivationdays of the primary cultured cells; and 2) these changes may provide clues about the developmental steps and the recovery process after neuron damage. Based on this opinion, the physiological function of BNIP-3 was estimated from the results of the expression pattern of its mRNA during the cultivation and the antidepressant effects on the expression, suggesting that BNIP-3 may be involved in the regrowth of the neurite, neuronal sprouting, and functional enhancement of the synapse. The short variant with sequence similarity to BNIP-3 mRNA was also found. Its expression level was high in the early stage of the neuron development, but further studies are necessary to determine the physiological functions and meanings.

\section{Competing interests}

The author declares that he has no competing interests.

\section{Acknowledgement}

This work was supported by a Grant-in-Aid for

Scientific Research (A) (\#21249047) from Japan

Society for the Promotion of Science (JSPS).

\section{Publication history}

Editor: Peter Illes, University of Leipzig, Germany.

Received: 18-Dec-2013 Revised: 24-Jan-2014

Accepted: 12-Feb-2014 Published: 24-Feb-2014

\section{References}

1. Tohda M, Hang PN and Matsumoto K. Developmental changes in serotonin $2 \mathrm{C}$ receptor mRNA editing in the rat cerebral cortex and primary cultured cortical neurons. Biol Pharm Bull. 2009; 32:289-92. I $\underline{\text { Article | PubMed }}$
2. Tohda M, Hayashi H, Sukma M and Tanaka K. BNIP-3: a novel candidate for an intrinsic depression-related factor found in NG108-15 cells treated with Hochu-ekki-to, a traditional oriental medicine, or typical antidepressants. Neurosci Res. 2008; 62:1-8. | Article I PubMed

3. Tohda M, Mingmalairak S, Murakami Y and Matsumoto K. Enhanced expression of BCL2/adenovirus EIB 19-kDa-interacting protein 3 mRNA, a candidate for intrinsic depression-related factor, and effects of imipramine in the frontal cortex of stressed mice. Biol Pharm Bull. 2010; 33:53-7. I Article I PubMed

4. Li R, Yan G, Li Q, Sun H, Hu Y, Sun J and Xu B. MicroRNA-145 protects cardiomyocytes against hydrogen peroxide $(\mathrm{H}(2) \mathrm{O}(2))$-induced apoptosis through targeting the mitochondria apoptotic pathway. PLOS One. 2012; 7:e44907. | Article | PubMed Abstract | PubMed Full Text

5. Brewer GJ. Serum-free B27/neurobasal medium supports differentiated growth of neurons from the striatum, substantia nigra, septum, cerebral cortex, cerebellum, and dentate gyrus. J Neurosci Res. 1995; 42:674-83. | Article | PubMed

6. Tohda $M$, Sukma $M$, Nomura $Y$ and Watanabe $H$. The mRNA expression of serotonin 2C subtype receptors uncoupled with inositol hydrolysis in NG108-15 cells. Jpn J Pharmacol. 2002; 90:138-44. | Article I PubMed

7. Tohda M, Sukma M and Watanabe H. RNA editing and short variant of serotonin 2C receptor mRNA in neuronally differentiated NG108-15 cells. J Pharmacol Sci. 2004; 96:164-9. | Article | PubMed

8. Kim M, Hersh LB, Leissring MA, Ingelsson M, Matsui T, Farris W, Lu A, Hyman BT, Selkoe DJ, Bertram L and Tanzi RE. Decreased catalytic activity of the insulin-degrading enzyme in chromosome 10-linked Alzheimer disease families. J Biol Chem. 2007; 282:7825-32. | Article I PubMed

9. Berezovskaya O, Maysinger D and Fedoroff S. Colony stimulating factor-1 potentiates neuronal survival in cerebral cortex ischemic lesion. Acta Neuropathol. 1996; 92:479-86. | Article | PubMed

10. Obi R, Tohda M, Zhao Q, Obi N, Hori H, Murakami Y, Goto H, Shimada Y, Ochiai $\mathrm{H}$ and Matsumoto $\mathrm{K}$. Chotosan enhances macrophage colonystimulating factor mRNA expression in the ischemic rat brain and C6Bu1 glioma cells. Biol Pharm Bull. 2007; 30:2250-6. | Article I PubMed

11. Takeuchi A, Miyaishi O, Kiuchi K and Isobe K. Macrophage colonystimulating factor is expressed in neuron and microglia after focal brain injury. J Neurosci Res. 2001; 65:38-44. I Article I PubMed

12. Du Yan S, Zhu H, Fu J, Yan SF, Roher A, Tourtellotte WW, Rajavashisth T, Chen X, Godman GC, Stern D and Schmidt AM. Amyloid-beta peptidereceptor for advanced glycation endproduct interaction elicits neuronal expression of macrophage-colony stimulating factor: a proinflammatory pathway in Alzheimer disease. Proc Natl Acad Sci U S A. 1997; 94:5296301. | Article | PubMed Abstract | PubMed Full Text

13. Leissring MA, Lu A, Condron MM, Teplow DB, Stein RL, Farris W and Selkoe DJ. Kinetics of amyloid beta-protein degradation determined by novel fluorescence- and fluorescence polarization-based assays. J Biol Chem. 2003; 278:37314-20. | Article | PubMed

14. Chapman ER. How does synaptotagmin trigger neurotransmitter release? Annu Rev Biochem. 2008; 77:615-41. | Article I PubMed

15. Hunter $S$ and Brayne $C$. Relationships between the amyloid precursor protein and its various proteolytic fragments and neuronal systems. Alzheimers Res Ther. 2012; 4:10. I Article I PubMed Abstract | PubMed Full Text

16. Lazarov O and Demars MP. All in the Family: How the APPs Regulate Neurogenesis. Front Neurosci. 2012; 6:81. | Article | PubMed Abstract | PubMed Full Text

17. Canton H, Emeson RB, Barker EL, Backstrom JR, Lu JT, Chang MS and Sanders-Bush E. Identification, molecular cloning, and distribution of a short variant of the 5-hydroxytryptamine2C receptor produced by alternative splicing. Mol Pharmacol. 1996; 50:799-807. | Article | PubMed

18. Doe CM, Relkovic D, Garfield AS, Dalley JW, Theobald DE, Humby T, Wilkinson LS and Isles AR. Loss of the imprinted snoRNA mbii-52 leads to increased 5htr2c pre-RNA editing and altered 5HT2CR-mediated behaviour. Hum Mol Genet. 2009; 18:2140-8. I Article I PubMed Abstract | PubMed Full Text 
19. Tohda M, Hang PT, Kobayashi N and Matsumoto K. Serotonin $2 \mathrm{C}$ receptor (5-HT2CR) mRNA editing-induced down-regulation of 5-HT2CR function in Xenopus oocytes: the significance of site C editing. J Pharmacol Sci. 2010; 113:362-7. | Article | PubMed

20. Opazo P, Sainlos M and Choquet D. Regulation of AMPA receptor surface diffusion by PSD-95 slots. Curr Opin Neurobiol. 2012; 22:453-60. | Article I PubMed

21. Sturgill JF, Steiner P, Czervionke BL and Sabatini BL. Distinct domains within PSD-95 mediate synaptic incorporation, stabilization, and activity-dependent trafficking. J Neurosci. 2009; 29:12845-54. | Article | PubMed Abstract | PubMed Full Text

22. Todd $\mathrm{PK}$, Mack KJ and Malter JS. The fragile $X$ mental retardation protein is required for type-I metabotropic glutamate receptor-dependent translation of PSD-95. Proc Natl Acad Sci U S A. 2003; 100:14374-8. | Article | PubMed Abstract | PubMed Full Text

23. Muddashetty RS, Nalavadi VC, Gross C, Yao X, Xing L, Laur O, Warren ST and Bassell GJ. Reversible inhibition of PSD-95 mRNA translation by miR-125a, FMRP phosphorylation, and mGluR signaling. Mol Cell. 2011; 42:673-88. | Article | PubMed Abstract | PubMed Full Text

24. Nordman JC and Kabbani N. An interaction between alpha7 nicotinic receptors and a G-protein pathway complex regulates neurite growth in neural cells. J Cell Sci. 2012; 125:5502-13. | Article I PubMed

25. Tohda M, Suwanakitch $P$, Jeenapongsa R, Hayashi $H$, Watanabe $H$ and Matsumoto K. Expression changes of the mRNA of Alzheimer's disease related factors in the permanent ischemic rat brain. Biol Pharm Bull. 2004; 27:2021-3. | Article | PubMed

\section{Citation:}

Tohda M. Changes in the expression of BNIP-3 and other neuronal factors during the cultivation period of primary cultured rat cerebral cortical neurons and an assessment of each factor's functions. Cell Signal Traffic. 2014; $2: 1$. http://dx.doi.org/10.7243/2054-1481-2-1 